\section{Mislabelling of Döner kebab sold in Italy}

\author{
Gaetano Liuzzo, ${ }^{1}$ Roberto Rossi, ${ }^{1}$ \\ Federica Giacometti, ${ }^{2}$ Silvia Piva, ${ }^{2}$ \\ Andrea Serraino, ${ }^{2}$ Giulia Mescolini, ${ }^{2}$ \\ Gianfranco Militerno ${ }^{2}$
}

1 Modena Local Health Authority, Carpi District, Carpi (MO); ' ${ }^{2}$ epartment of Veterinary Medical Sciences, Alma Mater Studiorum-University of Bologna, Ozzano dell'Emilia (BO), Italy

\section{Abstract}

The aim of this study was to assess whether Döner kebabs sold in Italy comply with legal labelling requirements. A checklist of $\mathrm{EU}$ labelling requirements was drawn up and nine labels of Döner kebab marketed in the province of Modena were collected to evaluate the mandatory information laid down in article 9 of Regulation (EU) No 1169/2011 together with the mandatory requirements of Regulation (EC) 853/2004 for meat preparations. The study showed that different additives are commonly used in Döner kebabs, including E 621 (monosodium glutamate). This additive is not included among the ingredients authorized for the meat preparation food category. Eight frozen Döner kebab samples were taken and a visual assessment and a histologic examination were performed to verify potential changes in the meat's inner muscle fibre structure that could allow the product to be considered among meat preparations or meat products. The Döner kebab labels showed several systematically deficient regulatory requirements in both extrinsic defects (not related to food composition) and aspects concerning the protection of consumers' health. Histological examination showed that the tissue was moderately swollen, but the muscle fibre structure was intact. Kebab can be reasonably classified as a meat preparation thereby precluding the use monosodium glutamate (E 621 ) as an ingredient.

\section{Introduction}

Döner kebab is a traditional Turkish gastronomic meat preparation. It is produced starting from whole or minced meat marinated for 12 hours at $4^{\circ} \mathrm{C}$ with red or black pepper, salt, onion powder or pieces, sliced tomato or tomato sauce, olive oil, lemon juice, vinegar, milk or milk powder, yogurt and eggs (Vazgecer et al., 2004). After that, the kebab is shaped like a cone around a skewer then frozen for distribution to mass caterers and administration to final consumers. Döner kebab in a block is cooked vertically on roller grill skewers. During cooking, the cooked part is cut away using a long bladed or circular knife and stuffed into pita bread along with sliced tomatoes, onions, lettuce and served with other typical oriental sauces like hummus or tabbouleh.

Döner kebab chemical-physical characteristics are variable: humidity varies from 48 to $69 \%$, pH ranges from 5.7 to 6.0 and the water activity varies between 0.94 and 0.95 (Kilic, 2009). On the basis of Regulation (EC) No 853/2004 (European Commission, 2004), Döner kebab could be classified as a meat preparation which means fresh meat, including meat that has been reduced to fragments, which has had foodstuffs, seasonings or additives added to it or which has undergone processes insufficient to modify the internal muscle fiber structure of the meat and thus to eliminate the characteristics of fresh meat. As such it is included in the Guidance document describing the food categories in Part E of Annex II to Regulation (EC) No 1333/2008 on Food Additives (European Commission, 2008). The Annex also lists the additives authorized for use in the preparation of this food.

The aim of this study was to ascertain if Döner kebabs sold on the Italian market as meat preparations comply with the labelling requirements of relevant $\mathrm{EU}$ legislation.

The labels listed different additives commonly used in Döner kebab ingredients, including E 621 (monosodium glutamate). This additive is not authorized for use in meat preparations so a histological evaluation was performed to assess whether Döner kebabs belong to the meat preparation food category and whether the use of additive E 621 complies with the EU Regulation on additives.

\section{Materials and Methods}

A checklist was used for the evaluation of regulatory labelling requirements. Nine labels of Döner kebab (produced with calf, turkey and chicken meat) marketed in the province of Modena, were collected to evaluate the mandatory information included in article 9 of Regulation (EU) No 1169/2011 together with the mandatory requirements of Regulation (EC) $853 / 2004$ for meat preparations (European Commission, 2004, 2011). According to art. 4 of Regulation (EU) 1169/2011 (European Commission, 2011), mandatory food information defined by the Community legislator falls into three categories: the identity, composition and properties of the food; the protection of consumers' health and safe use of food; the nutritional characteristics. The checklist aimed at evaluating only the first two categories, and not the
Correspondence: Andrea Serraino, Department of Veterinary Medical Sciences, Alma Mater Studiorum-University of Bologna, via Tolara di Sopra 50, 40064 Ozzano dell'Emilia (B0), Italy. Tel: +39512097323 ; Fax: +39512097346.

E-mail: andrea.serraino@unibo.it

Key words: Döner kebab; Label; Mislabeling; Additives.

Received for publication: 8 July 2016 .

Revision received: 5 August 2016.

Accepted for publication: 9 August 2016.

This work is licensed under a Creative Commons Attribution-NonCommercial 4.0 International License (CC BY-NC 4.0).

(C) Copyright G. Liuzzo et al., 2016

Licensee PAGEPress, Italy

Italian Journal of Food Safety 2016; 5:6149

doi:10.4081/ijfs.2016.6149

nutritional labelling. As it can be observed in Table 1, the section of mandatory identity information in the checklist included the name of the food, the list of ingredients, the quantity or categories of certain ingredients, the net quantity of the food, the name or business name and the address of the Food Business Operator (FB0) responsible for the information, the identification mark and the lot identification. The section of mandatory food information on protection of consumers' health in the checklist included the indication of ingredients or substances causing allergies (or intolerances), the date of minimum durability or the use by date, any special storage conditions and/or conditions of use and the instructions for use. To verify if Döner kebab could be classified in the meat preparations food category and consequently establish if some ingredients listed in the label were authorized, eight frozen Döner kebab samples were taken and a visual assessment and histologic examination were performed to verify potential changes in the meat muscle fibre structure. Samples were fixed in $10 \%$ buffered formalin at $\mathrm{pH}$ 7-7.6 for 24 hours, embedded in paraffin wax, sectioned at $5 \mu \mathrm{m}$, longitudinally and transversely, and stained with haematoxylin and eosin (H\&E) for histological examination.

\section{Results}

Results on the label evaluation are summarized in Table 1. The sampled kebabs were produced with calf, turkey and chicken meat. At macroscopic visual assessment, the Döner kebabs were frozen meat blocks wrapped in a transparent film. At histological examination, the muscular microscopic characteristics were 
substantially normal. Microscopic examination revealed longitudinal and perpendicular normal striated muscle fibers. These appeared diffusely eosinophilic, arranged in parallel, with peripheral elongated nuclei near the sarcolemma and typical cross streaks in most fields were observed (Figure 1). In cross-sections, the cells were round or polygonal in shape with peripheral nuclei (Figure 2). Furthermore, they were leaning against each other, with little or moderate interposed space, sometimes occupied by connective tissue of probable endomysial/perimysial or fascial origin. As a whole, the tissue was moderately swollen, but the structure of the muscle fibres was intact. Only in a few areas the tissue present signs of fragmentation, judged as artefacts caused by cutting several parts of partially thawed samples. Some of these aspects, such as fibre swelling, may have been caused by osmotic changes due to kebab preparation. Focal roundish greyish material, of probable exogenous origin, was visible among the muscle cells or inside the fibrous tissue at low and high magnification.

\section{Discussion}

The mandatory food information evaluated from a legislative perspective in this study concerned the identity, composition and properties of Döner kebabs, the protection of consumers' health and the safe use of the product. Regarding the mandatory information on identity, composition and properties, a high number of minor legislative non-conformities were found, emphasizing a scant knowledge of EU regulations or poor attention to regulation requirements (for example non conformities on the name of the food, the list of ingredients, the quantity of certain ingredients or categories of them, the net quantity, the name or business name and the address of the FBO responsible for the information, the batch identification); details are reported in Table 1.

Some important hygienic-sanitary conditions for the protection of consumer's health and the safe use of the product were inadequate. For example, in two of the nine labels analysed, the production plant whose approval number appeared on the labels was not authorized to produce meat preparations or meat products. None of the mandatory information on the minimum durability date and/or the use by date was expressed correctly. In one case, the minimum durability date was not printed

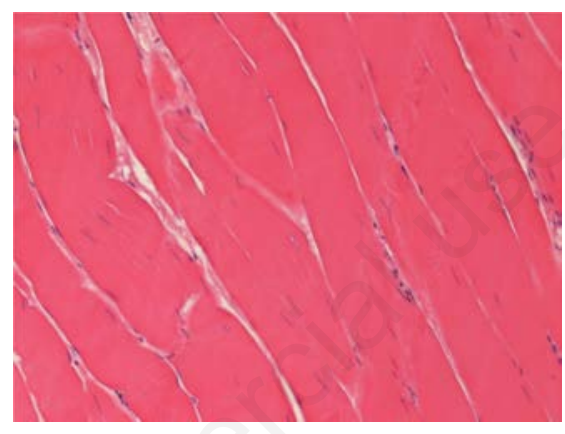

Figure 1. Histological image of Döner kebab. Longitudinal striated muscle fibres, with peripheral elongated nuclei. Haematoxylin and eosin staining, 200x. in Italian. For frozen meat preparations, the date of freezing (or the date of first freezing) must be specified and none of the labels complied with this rule. Furthermore the legislator established that if the product needs particular precautions, considering its nature, information must be given on the conditions of storage and use. As the product is frozen, storage conditions should be specified, but six of the nine labels did not comply with this requirement.

In addition, the instructions for use must be reported in such a way as to enable appropriate use of the food. This aspect is relevant for the FBO due to the peculiar cooking technique of kebab (progressive exposure to heat from the outer part to the centre of the meat block). The outcome of this procedure is that during cooking, that is generally long, the heart of kebab is subjected to a heat treatment in a temperature range of $25-45^{\circ} \mathrm{C}$. This may give rise to the

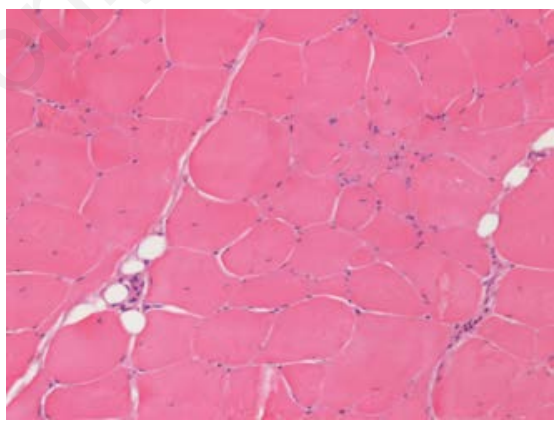

Figure 2. Histological image of Döner kebab. Cross-sections of striated muscle fibres, with peripheral nuclei. Haematoxylin and eosin staining, 200x.

Table 1. Checklist used to evaluate the compliance of nine Döner kebab labels to European Union regulatory requirements according to Regulation 1169/2011/EU and non-conformities found.

\begin{tabular}{|c|c|c|c|}
\hline Category & Examined information & abel NC (n) & NC description (non-compliant labels, $\mathrm{n}$ ) \\
\hline \multirow[t]{7}{*}{ Identity information } & Name of the food & 6 & $\begin{array}{l}\text { Absence of the indication of the physical condition of the food (6); } \\
\text { Absence of the indication of added proteins (2) }\end{array}$ \\
\hline & List of ingredients & 9 & $\begin{array}{l}\text { Incorrect indication of ingredients (9); } \\
\text { descending order of ingredients (2) }\end{array}$ \\
\hline & Quantity of certain ingredients or categories of them & 4 & $\begin{array}{l}\text { Absence of the indication of quantity of ingredients included } \\
\text { in the name of the food (4) }\end{array}$ \\
\hline & Net quantity & 1 & Absence of the indication of units of mass (1) \\
\hline & $\begin{array}{l}\text { Name or business name and the address } \\
\text { of the FBO responsible for the information }\end{array}$ & 3 & $\begin{array}{l}\text { The address on the label matches the production plant but not } \\
\text { trade mark proprietors' }(3)\end{array}$ \\
\hline & Identification mark or health mark & 3 & $\begin{array}{l}\text { Readability of the approval number }(1) \text {; } \\
\text { the production plant with the approval number did not } \\
\text { have an adequate approval for the production of meat } \\
\text { preparations (2) }\end{array}$ \\
\hline & Batch identification & 8 & $\begin{array}{l}\text { Absence of the lot number (3); lot wording did not comply } \\
\text { with the regulation (5) }\end{array}$ \\
\hline \multirow{4}{*}{$\begin{array}{l}\text { Information on protection } \\
\text { of consumers' health }\end{array}$} & Indication of substances causing allergies & 6 & Absence of indication of ingredients potentially causing allergies (6) \\
\hline & Date of minimum durability or use by date & 9 & $\begin{array}{l}\text { The date of minimum durability is not correctly indicated (4); } \\
\text { the use by date is not correctly indicated (5) }\end{array}$ \\
\hline & Special storage conditions and/or conditions of use & 6 & Storage conditions at freezing temperature (6) \\
\hline & Instructions for use & 3 & Absence of instructions for use (3) \\
\hline
\end{tabular}

NC, non-conformity; FBO, food business operator. 
replication of any pathogens present in the raw product (Kilic, 2009). Döner kebabs have often been identified as vehicles for foodborne pathogens such as Clostridium perfringens, Salmonella spp. and Staphylococcus aureus (Kayisoglu et al., 2003; Food Standard Agency, 2005; Ziino et al., 2013). Evaluation of kebab labels must address the problem of information on the proper storage conditions for the product unsold at the end of the day that is regulated by national agencies (Food Standard Agency, 2005; NSW Food Authority, 2012).

The FB0 preparing Döner kebabs for consumption must provide information to consumers on any allergenic substances that may be present. The indication of substances or products that may cause allergies or intolerances was absent in five of the nine labels examined, thereby limiting the possibility for the FBO to communicate useful information to consumers with food allergies.

The Döner kebab labels analysed in this study listed different additives commonly used in Döner kebab ingredients, including E 621 (monosodium glutamate). Our microscopic and macroscopic examination showed that the kebab samples analysed can be classified as meat preparations for which the use of additive $\mathrm{E} 621$ is not authorized.

\section{Conclusions}

In conclusion, our study disclosed several systematically deficient regulatory requirements in Döner kebab labelling, both for extrinsic defects (not related to food composition) and for aspects concerning the protection of consumers' health that may influence the safety of Döner kebabs.

\section{References}

European Commission, 2004. Regulation of the European Parliament and of the Council of 29 April 2004 laying down specific hygiene rules for food of animal origin, 853/2004/EC. In: Official Journal, L 139/55, 30/04/2004.

European Commission, 2008. Regulation of the European Parliament and of the Council of 16 December 2008 on food additives, 1333/2008/EC. In: Official Journal, L $354 / 16,31 / 12 / 2008$.

European Commission, 2011. Regulation of the European Parliament and of the Council of 25 October 2011 on the provision of food information to consumers, amending Regulations (EC) No 1924/2006 and (EC) No 1925/2006 of the European
Parliament and of the Council, and repealing Commission Directive 87/250/EEC, Council Directive 90/496/EEC, Commission Directive 1999/10/EC, Directive 2000/13/EC of the European Parliament and of the Council, Commission Directives 2002/67/EC and 2008/5/EC and Commission Regulation (EC) No 608/2004, 1169/2011/EU. In: Official Journal, L 304/18, 22/11/2011.

Food Standard Agency, 2005. Food Standard Agency annual report 2004. Food Standard Agency, London, UK.

Kayisoglu S, Yilmaz I, Demirci M, Yetim H, 2003. Chemical composition and microbiolical quality of the döner kebabs sold in Tekirdag market. Food Control 14:469-74.

Kilic B, 2009. Current trends in traditional Turkish meat products and cuisine. LWTFood Sci Technol 42:1581-9.

NSW Food Authority, 2012. Döner kebabs. NSW/FA/FI019/0911. Available from: http://www.foodauthority.nsw.gov.au/_Doc uments/retailfactsheets/doner_kebabs.pdf

Vazgecer B, Ulu H, Oztan A, 2004. Microbiological and chemical qualities of chicken_döner_kebab retailed on the Turkish restaurants. Food Control 15:2614.

Ziino G, Gurrera G, Beninati C, 2013. Microbiological quality of kebabs sold in Palermo and Messina. Ital J Food Safety 2:77-80. 